\title{
Role-sharing through Studio-Collaboration Based Learning: Lecturer-Student-SME's Owner Scheme
}

\author{
Bayyinah Nurrul Haq ${ }^{1}$ \\ ${ }^{1}$ Faculty of Creative Industry dan Telematic, Trilogy University,Indonesia \\ 'bayyinah.nh@trilogi.ac.id
}

\begin{abstract}
This paper discusses the design process experienced by industrial design students from the role sharing of lecturers - students - SMEs. A case study from a lecture at the design studio class of the Trilogy University which project theme aims to design a product according to the needs of the SME where they collaborate. The design stage conducted by students includes design research, concept development, exploration, production, and final presentation. The case study research is conducted in a descriptive qualitative. The results show differences in role sharing between lecturers - students - SME's owner due to differences in the type and background of the SME, business strategy andeducational background of SME's owner. To deal with these differences requires lecturers who have competence as, facilitators, and instructors.
\end{abstract}

Keywords: Studio Based Learning, role sharing, Product development process

\section{INTRODUCTION}

Studio-based learning (SBL) is a major course in product design majors that introduces core skills as problem-solving from the real world [1], design methods [2], and decision making through direct practice [1]-[5]. SBL courses generally have large credit scores as in [1], [2], [6]they require students to spend time in studio classes, workshops or doing field research. There is a similarity between SBL and Project-Based Learning (PBL) as a learning model referred to terms of its purpose and process and learning outcomes. Both SBL and PBL asks students to complete assignments in the form of projects for one semester [1], [6], [7]. Different from PBL that gives a clear problem and guideline [8], the task that becomes the project in SBL is an open problem, an ill-defined problem, an unsolved problem [1], [8]. Another distinct is the collaboration of lecturer and student interaction in SBL as in [2], [9] shows interaction that allows them to experience the division of roles get or provide feedback. The changing role's purposes are to achieve the expected final design, alternative solutions, or decide the stagnation of ideas[8], [10]. Research shows how campus invites partners from the community or industry to collaborate with students during the implementation of SBL to get an authentic experience in the industry[2], [3], [8], [11]. This effort gave positive results to various parties such as students get an authentic experience in the industry, meet and interact with designers or professionals in the industry[2], [8], [12]. This also provides motivation and reinforces the implementation goals of SBL [10], [11].The benefits for lecturers are as innovative learning strategies shows in [2], [8], [10]. While the benefits for the community or Small Medium Enterprises (SME) owners are getting ideas and new innovative product solutions [5], [8], [10]. 
This study discusses the sharing of roles between Lecturers - students and community or SME owners during Studio lectures interaction at Trilogy University. The theme of the studio project is Design-based Product Design for SMEs. The division of roles is reviewed from each stage of the design process carried out during Studio lectures. The design process that is used as a reference is the flow that discussed in Wodehouse (2010) which simplified into four stages activities, namely: 1) Data gathering 2) Concept development 3) Exploration 4) Production Ramp-up - Production - prototyping[12].

\section{METHOD}

This study was descriptive qualitative by using a case study approach, so it needs to understand every phenomenon related to its context[7]. The Case study was conducted in Industrial Design at Trilogy University (DP), Jakarta.

Data is collected through interviews, observations during learning activities, study of documents related to learning activities and results. Data analysis was carried out in a qualitative descriptive manner[7]. There are 4 samples of students used as study material in this paper, named with initial RAN, MAR, RIN and RIS. Each student chooses a different SME. Two students carry out collaborations at SME which are purely business-oriented while the other at a sociopreneur-based SME. All four SMEs are based in Jakarta and surrounding areas, but one SME carries out production in two different places (Jakarta - East Nusa Tenggara).

Implementation of DP SME lectures studio consists of 14-16 weeks. Every seven weeks the lectures are held in the form of presentations in class which are witnessed by friends and fellow lecturers outside the lecturer supporting the course. Table 1 shows the flow of learning activities of DP SME students.

\begin{tabular}{|c|c|c|c|c|}
\hline Design Stage & Schedule & Lecturer & Student & SME's owner \\
\hline \multirow{6}{*}{$\begin{array}{l}\text { Design } \\
\text { Research }\end{array}$} & Week & Introductory: & Action Plan & \\
\hline & $1-2$ & $\begin{array}{l}\text { SME in Indonesia } \\
\text { Survey Briefing }\end{array}$ & Look for SME & \\
\hline & $\begin{array}{l}\text { Week } \\
3-4\end{array}$ & $\begin{array}{l}\text { Progress report } \\
\text { reviewer }\end{array}$ & $\begin{array}{l}\text { The survey, Observe, } \\
\text { Interview SME }\end{array}$ & Interviewer/respondent \\
\hline & & & $\begin{array}{l}\text { Apply for design } \\
\text { contract }\end{array}$ & $\begin{array}{l}\text { Accept/reject design } \\
\text { contract }\end{array}$ \\
\hline & & & Compile progress report & $\begin{array}{l}\text { Data provider, } \\
\text { Production Facilities } \\
\text { provider }\end{array}$ \\
\hline & $\begin{array}{l}\text { Week } \\
5-6\end{array}$ & $\begin{array}{l}\text { Report analysis } \\
\text { reviewer }\end{array}$ & Data analysis & $\begin{array}{l}\text { Data provider, } \\
\text { Production Facilities } \\
\text { provider } \\
\text { Report analysis reviewer }\end{array}$ \\
\hline \multirow[t]{3}{*}{$\begin{array}{l}\text { Concept } \\
\text { Development }\end{array}$} & $\begin{array}{l}\text { Week } \\
7\end{array}$ & $\begin{array}{l}\text { Progress report } \\
\text { reviewer }\end{array}$ & Progress Report & - \\
\hline & $\begin{array}{l}\text { Week } \\
8\end{array}$ & & $\begin{array}{l}\text { Mood Board analysis } \\
\text { Concept design } \\
\text { development }\end{array}$ & - \\
\hline & & & Design Decision & $\begin{array}{l}\text { Accept/reject design } \\
\text { decision }\end{array}$ \\
\hline Exploration & $\begin{array}{l}\text { Week } \\
9-12\end{array}$ & $\begin{array}{l}\text { Progress Report } \\
\text { reviewer }\end{array}$ & $\begin{array}{l}\text { Design Exploration } \\
\text { Progress Report }\end{array}$ & Design reviewer \\
\hline
\end{tabular}




\begin{tabular}{lllll} 
& Week 13 & Reviewer & Design Decision & $\begin{array}{l}\text { Accept/reject design } \\
\text { decision }\end{array}$ \\
\hline $\begin{array}{l}\text { Production } \\
\text { Prototyping }\end{array}$ & Week & & Production - Ramp Up & $\begin{array}{l}\text { Production Facilities } \\
\text { provider } \\
\text { Prototyping supervisor }\end{array}$ \\
\hline Final Presentation & Week 17 16 & Reviewer & Design Presentation & -
\end{tabular}

\section{RESULT AND DISCUSSION}

\subsection{Result}

Based on the learning process there was a picture that showed a division of roles between lecturers - SMEs Owner - Students. This relates to the learning objectives, competencies expected to be obtained by students. The description at each stage is as follows:

\section{a. Design research stage}

The four students carried out the design research stage in two places, at the SME location, and on-campus for the needs of data collection, data analysis, and progress assistance. There are differences in the process of the four associated with this type of SMEs in terms of displaying information about the business profile, details of the research stage shown in table 2.

Table 2.Design research stage on Studio DP UKM

\begin{tabular}{lllll} 
& \multicolumn{1}{c}{ RAN } & \multicolumn{1}{c}{ MAR } & \multicolumn{1}{c}{ RIS } \\
\hline Data gathering & Interview & Interview & Interview & Interview \\
\hline Data Source & $\begin{array}{l}\text { Website } \\
\text { Owner }\end{array}$ & $\begin{array}{l}\text { Website } \\
\text { Owner }\end{array}$ & Owner & Owner \\
\hline $\begin{array}{l}\text { Data analyzing } \\
\text { method }\end{array}$ & $\begin{array}{l}\text { SWOT analysis } \\
\text { Product Portfolio analysis }\end{array}$ & SWOT analysis & $\begin{array}{l}\text { SWOT analysis } \\
\text { Product Portfolio } \\
\text { analysis }\end{array}$ & $\begin{array}{l}\text { SWOT } \\
\text { analysis } \\
\text { Product } \\
\text { Portfolio } \\
\text { analysis }\end{array}$ \\
\hline $\begin{array}{l}\text { Problem } \\
\text { defining }\end{array}$ & & & & "need a new \\
& "trend demands require & "need a new & "need a new product \\
new styles development " & product line" & theme" & theme" \\
\hline $\begin{array}{l}\text { Lecturer's } \\
\text { Response }\end{array}$ & $\begin{array}{l}\text { depends on SME's owner's } \\
\text { decision }\end{array}$ & Agree & Agree & SME's \\
& & & & owner's \\
decision
\end{tabular}

\section{b. Concept development}

The SME category based on its business base influenced in this phase. There are some differences in responses to the submission of solutions by students. Table 3 shows how MAR and RIS implement collab - design in sociopreneur-based SMEs. Whereas RAN and RIN work with SME based entrepreneurial businesses.

Table 3. Concept development stage on Studio DP UKM

\begin{tabular}{|c|c|c|c|c|}
\hline & RAN & MAR & RIN & RIS \\
\hline \multirow[t]{2}{*}{$\begin{array}{l}\text { Design } \\
\text { Innovation } \\
\text { (proposal) }\end{array}$} & $\begin{array}{l}\text { Making existing types, } \\
\text { developing new material } \\
\text { blends }\end{array}$ & $\begin{array}{lr}\text { Create } & \text { new types } \\
\text { that } & \text { integrate } \\
\text { existing } & \text { product } \\
\text { features } & \end{array}$ & $\begin{array}{l}\text { Make an existing } \\
\text { type but change } \\
\text { some parts }\end{array}$ & $\begin{array}{l}\text { Open new market } \\
\text { Develop new } \\
\text { techniques and } \\
\text { materials (additions) }\end{array}$ \\
\hline & $\begin{array}{l}\text { Rattan coffee table, top } \\
\text { table made of glass }\end{array}$ & $\begin{array}{l}\text { Card wallet as well } \\
\text { as a coin wallet }\end{array}$ & $\begin{array}{l}\text { Sandal shoes - } \\
\text { sling back with a } \\
\text { Betawi theme }\end{array}$ & $\begin{array}{l}\text { an easy chair with a } \\
\text { wooden frame is } \\
\text { covered with a } \\
\text { woven newspaper }\end{array}$ \\
\hline
\end{tabular}


which is rolled and

woven

\begin{tabular}{|c|c|c|c|c|}
\hline & $\begin{array}{l}\text { Rattan is a new material } \\
\text { that tested by the } \\
\text { company recently. }\end{array}$ & $\begin{array}{l}\text { SME standard } \\
\text { material }\end{array}$ & $\begin{array}{l}\text { SME standard } \\
\text { material }\end{array}$ & $\begin{array}{l}\text { Chair frame material } \\
\text { has never been used } \\
\text { by the company. } \\
\text { Used newsprint } \\
\text { material is the main } \\
\text { raw material } \\
\text { available at the SME }\end{array}$ \\
\hline & $\begin{array}{l}\text { Try a new style that will } \\
\text { be carried by the } \\
\text { company next year. }\end{array}$ & $\begin{array}{l}\text { Following the style, } \\
\text { which is already } \\
\text { there. }\end{array}$ & $\begin{array}{l}\text { Following the style, } \\
\text { which is already } \\
\text { there. }\end{array}$ & $\begin{array}{l}\text { Try a new style with } \\
\text { an existing "feel". }\end{array}$ \\
\hline $\begin{array}{l}\text { Business } \\
\text { innovation }\end{array}$ & $\begin{array}{l}\text { Opening up Business to } \\
\text { Business type market } \\
\text { opportunities }\end{array}$ & $\begin{array}{l}\text { the same segment, } \\
\text { target, market } \\
\text { strategy }\end{array}$ & $\begin{array}{l}\text { the same segment, } \\
\text { target, market } \\
\text { strategy }\end{array}$ & $\begin{array}{lr}\text { the same } & \text { segment, } \\
\text { target, } & \text { market } \\
\text { strategy } & \\
\end{array}$ \\
\hline $\begin{array}{l}\text { Lecturer's } \\
\text { Response } \\
\end{array}$ & Agree & Agree & Agree & $\begin{array}{l}\text { depends on SME's } \\
\text { owner's decision }\end{array}$ \\
\hline $\begin{array}{l}\text { SME's } \\
\text { Owner } \\
\text { Response }\end{array}$ & Agree to the terms & Agree & Strongly agree & Agree to the terms \\
\hline
\end{tabular}

\section{c. Exploration - testing and refinement}

Students activities on this phase are test concepts by making visualizations, presentations in the form of sketches, drawings, 3D drawing, and submission of material charts. During the 9th-12th week, students did more independent exploration work, because the SMEs that were used as collab sites generally did not have facilities for drawing. Like on-campus or at a student's home.Table 4 shows differences in where, how, and the results of student activities in this phase.

Table 4.Exploration, testing and refinement stage on Studio DP UKM

\begin{tabular}{|c|c|c|c|c|}
\hline & RAN & MAR & RIN & RIS \\
\hline Sketches/drawing & At home & On campus & On campus & On campus \\
\hline 3D drawing & At home & On campus & On campus & At home \\
\hline Detail drawing & At campus & At home & SME & At home \\
\hline $\begin{array}{l}\text { Lecturer's } \\
\text { Response }\end{array}$ & $\begin{array}{l}\text { the proposed design } \\
\text { is understandable } \\
\text { but asks some } \\
\text { improvement. }\end{array}$ & $\begin{array}{l}\text { the proposed design } \\
\text { is understandable } \\
\text { but asks for SME's } \\
\text { opinion. }\end{array}$ & $\begin{array}{l}\text { the proposed design is } \\
\text { understandable but } \\
\text { asks for SME's } \\
\text { opinion. }\end{array}$ & $\begin{array}{l}\text { the proposed } \\
\text { design was less } \\
\text { understandable } \\
\text { and asks for } \\
\text { SME's opinion. }\end{array}$ \\
\hline $\begin{array}{l}\text { SME's Owner } \\
\text { Response }\end{array}$ & Agree to the terms & Agree to the terms & $\begin{array}{l}\text { some of the designs } \\
\text { submitted were highly } \\
\text { approved }\end{array}$ & $\begin{array}{l}\text { the design } \\
\text { submitted was } \\
\text { less preferred }\end{array}$ \\
\hline
\end{tabular}

\section{d. Production ramp up - prototyping}

After the final design is approved and deemed ready for production, four students experienced varies conditions. Table 5 shows this condition is influenced by the basis of the SME where they collab. RAN and RIS who innovate the use of materials for their design faced production constraints.According to the final design, SME where RAN collab is not ready to produce. SME's machine operators are not ready to combine two materials that have different production techniques, so 3-4 weeks is considered inadequate.

MAR has been hampered by the availability of main material, tenun ikat fabric. The fabric is only produced two to three times a year. If there is no material stock, the SME will not produce. To outsmart the situation MAR must find other materials that have the same character and do production in SME. 
The SME where RIN collab is a conventional entrepreneur-based SME. As a conventional entrepreneur, having strength in terms of material stock and reliable craftsmen. SME's owner always chooses designs that still have the same product form and usage, the use of materials and the same design details. Because the RIN design does refer to existing designs, the production process runs smoothly according to the specified time target.

RIS collab at a community-based sociopreneur SME, apparently, they are not ready to produce furniture based on wood frames. That material has never been used before. They asked RIS to work on the framework outside the community, and do the rest in the community.

Table 5.Production ramp up, prototyping stage on Studio DP UKM

\begin{tabular}{lllll} 
& \multicolumn{1}{c}{ RAN } & \multicolumn{1}{c}{ MAR } & \multicolumn{1}{c}{ RIN } & RIS \\
\hline Material & $\begin{array}{l}\text { The new material } \\
\text { available }\end{array}$ & $\begin{array}{l}\text { Raw material not } \\
\text { available }\end{array}$ & $\begin{array}{l}\text { All material } \\
\text { available }\end{array}$ & $\begin{array}{l}\text { The new material } \\
\text { not available }\end{array}$ \\
\hline Method & $\begin{array}{l}\text { The new technique } \\
\text { that the operator can } \\
\text { learn. }\end{array}$ & Same technique & Same technique & $\begin{array}{l}\text { the new technique, } \\
\text { rejected by all } \\
\text { operators. }\end{array}$ \\
\hline $\begin{array}{l}\text { Machine } \\
\text { /operator }\end{array}$ & $\begin{array}{l}\text { Tools are available, } \\
\text { the target date }\end{array}$ & $\begin{array}{l}\text { Tools available, Time } \\
\text { approved }\end{array}$ & $\begin{array}{l}\text { Tools are } \\
\text { available, the } \\
\text { target date agreed. }\end{array}$ & $\begin{array}{l}\text { Tool not available, } \\
\text { Time disapproved. }\end{array}$ \\
\hline $\begin{array}{l}\text { Lecturer's } \\
\text { Response }\end{array}$ & $\begin{array}{l}\text { recommend a design } \\
\text { revision }\end{array}$ & $\begin{array}{l}\text { recommends looking } \\
\text { for materials with the } \\
\text { same character }\end{array}$ & $\begin{array}{l}\text { Production Plan } \\
\text { approved }\end{array}$ & $\begin{array}{l}\text { recommend a design } \\
\text { revision }\end{array}$ \\
\hline $\begin{array}{l}\text { SME's Owner } \\
\text { Response }\end{array}$ & $\begin{array}{l}\text { Accepted on condition } \\
\text { Asked to look } \\
\text { elsewhere for certain } \\
\text { parts }\end{array}$ & Willing to production & Willing to & $\begin{array}{l}\text { Accepted on } \\
\text { production } \\
\text { Asked } \\
\text { elsewhere for certain } \\
\text { parts }\end{array}$ \\
& & & & look
\end{tabular}

\subsection{Discussion}

Based on observations, it turns out that there is a change in the role of the Lecturer Student - SME 's owner, in SBL practice generally what happens in class is the role of the Lecturer/staff as a decisive client in the client - servicing model [4]. In this case, what happens is the difference in the roles of the three affected by 1) type of company, 2) type of product 3) marketing strategy and product sales. The explanation is as follows:

- Division of roles influenced by types of SMEs - challenges for design students

There is a difference between sociopreneur-based SME and pure entrepreneur-based SME. At pure entrepreneur-based SMEs students are challenged with business strategies that run in the company. The student problems are the concept design development and a design exploration that must proceed according to the rules of SME's Owner.

While in sociopreneur-based SMEs, the challenge is the organizational culture that will affect production ramp - prototyping. At the SMEs, the student faced design constraints, such as material availability and craftsman skills that must be taken into account from the start. The consequence is the final design chosen must be completely changed to accommodate material or craftsmen problem. Material unavailability happened because it has not been produced by the community due seasonal production. Craftsmen problem occurs when they do not master the production technique associated with the selected design.

In the previous research, the refinement process occurred after collaboration between lecturers and peers only, because students had discretion in the production ramp - prototyping 
ramp [9]. They will only depend on on-campus facilities. In this case, SME has a strong role in determining decision making in terms of generating concepts and design refinements.

- The division of roles is influenced by the background of SME's Owner - innovation and decision making

Factors affecting the level of product innovation in the company is the designer of decision freedom in exploration and exploitation of the design [5]. In this case, innovation and designer freedom are influenced by the background of the SME's owner.

There are different ways of implementation between SMEs that have traditional entrepreneurial with modern entrepreneurs. This grouping is viewed from the background of SME's owner regarding the educational background related to the design or salesentrepreneurs. Traditional SMEs tend to emphasize the development of existing products based on their experience. So that product innovation is carried out only in the area of changes in shape, color, blend of materials that already exist in the factory or consumer tastes that are recognized by SME's owner. This shows how students learn about intuitive thinking in decision making from the real world[1], [10].

On the other hand, product development at SME's that has a design school background or the like tends to expect students to innovate in-line with marketing strategies, design styles that are / will be developed. It is a familiar condition with the design process that is usually done in the classroom, but students still find challenges in interpreting the product innovation strategy in the modern SME into the testing - refinement phase, especially in the form of drawings, sketches, and tastes[8].

- The role of lecturers as facilitators in each design stage

Lecturers act as monitors, providers of information and at the same time always reflect on each process that is being undertaken by students. This is influenced by the consideration of competencies that affect the success of students who must be prepared from the beginning[2], [6]. Competencies that play a role in the success of studio collaboration -based learning projects that involve the SME are:

Students research abilities in the design research stage include the ability to interpret data, do framing precisely the various problems of products owned by SME. Proper framing can be categorized as an intuition area, because not all decisions are purely on the results of data analysis[3], [12].

Communication skills, especially in terms of negotiations with people from various social, economic and educational backgrounds. The flexibility of interpersonal communication affects the smoothness of each design stage experienced, especially when in the SME environment[1], [9].Time management capabilities, related to the maturity of the calculation of the length of time of production and determine the tolerance of delay. Students are faced with a real manufacturing process, various technical obstacles that are only found in the real world[2].

These things are soft skills that lecturers may need to prepare from the start, simulations in class can be an alternative to introduce design research methods and communication techniques, negotiations[4], [8].In studio-based learning, generally, the lecturer-student activities that occur are assistance, evaluation, giving direction and advice. Referring to Diaz (2017)the difference ina design process that each design student goes through will vary depending on the fieldwork, the type of project, and the institution where the designer works[6]. Then a reflection session with students is needed for each process that has been undertaken either individually or together. This is to bridge the gap between the design process that is studied theoretically with its practice in the real world[1], [6]. In the end, students will build a complete conclusion on the learning process that they have passed [13]. 


\section{CONCLUSION}

The studio-based learning - collaboration approach based on this experience, shows the difference in the role sharing between lecturer - student - SME's owner. This difference promises positive things in studio-based learning innovation. Students as the center of learning activities get a lot of insight, find different perspectives on problems to understand unique design decisions. SME which is part of design collaboration gets new insights from a theoretical academic point of view to carry out design innovations. The lecturer gained experience as a facilitator who could oversee outside the ring but occasionally becomes an instructor that had to be able to take control to correct the bad conditions faced by students when they made mistakes.

\section{REFERENCES}

[1] K. Heikkinen, S. Ulla-maija, and J. Isokangas, "Entrepreneurship Education in Studio Based Learning Practices," in Entrepre- neurship Education in Studio Based Learning Practices. Proceedings of the 11th European Conference on Innovation and Entrepreneurship, 2016, pp. 247-256.

[2] H. Chen, Wenzhi, and Hui Tang, "Exploring the Learning Problems and Resources Usage of Undergraduate Industrial Design Students in Design Studio," in A. Marcus (Ed.): Design, User Experience, and Usability, Pt I, HCII 2011, LNCS 6769, pp. 43-52, 2011. C), 2011, vol. 6769, no. PART 1, pp. 323-331.

[3] K. Cennamo et al., "Managing the complexity of design problems through studio-based learning," Interdiscip. J. Probl. Learn., vol. 5, no. 2, p. 5, 2011.

[4] L. Moody, "Learning by doing: A studio-based approach to teaching ergonomics and human factors," in Proceedings of the 2011 ASEE Southeast Section Conference., 2011.

[5] E. M. Gerber, J. Marie Olson, and R. L. D. Komarek, "Extracurricular design-based learning: Preparing students for careers in innovation," Int. J. Eng. Educ., vol. 28, no. 2, p. 317, 2012.

[6] L. Pinchao Díaz, "Learning Process in Industrial Design, Analysis of the Learning Ways in Industrial Design Students," ICERI2017 Proc., vol. 1, no. February, pp. 4239-4247, 2017.

[7] M. Zahedi, "Exploring framing within a team of industrial design students," in DRS2016: FutureFocused Thinking, 2016, vol. 2, pp. 1-16.

[8] S. Clune, "Deep learning and industrial design education for sustainability," in Connected 2010 2nd International Conference on Design Education, 2010, pp. 1-5.

[9] M. Novoa, "Industrial Design Education as Innovation Broker through Making, Pivot Thinking, Autopoiesis and Expansive Learning," Des. Technol. Educ., vol. 23, no. 3, pp. 119-152, 2018.

[10] K. Tabeau et al., "Exploration and exploitation activities for design innovation," J. Mark. Manag., vol. 33, no. 3-4, pp. 203-225, 2016.

[11] P. di M. Rampino, Lucia, "The Innovation Pyramid: A Categorization of the Innovation Phenomenon in the Product - design," Int. J. Des., vol. 5, no. 1, pp. 3-16, 2016.

[12] A. J. Wodehouse and W. J. Ion, "Information use in conceptual design: Existing taxonomies and new approaches," Int. J. Des., vol. 4, no. 3, pp. 53-65, 2010.

[13] K. Saddhono, I. K. Sudarsana, and A. Iskandar, "Implementation of Indonesian Language The learning Based on Information and Communication Technology in Improving Senior High School Students' Achievement in Surakarta," in Journal of Physics: Conference Series, 2019, vol. 1254, no. 1, p. 12059. 